\title{
Representation of Women, Older Patients, Ethnic and Racial Minorities in Trials of Atrial Fibrillation
}

\author{
Muhammad Khan ${ }^{1}$, Muhammad Bilal Munir ${ }^{2}$, Safi Khan ${ }^{3}$, Charumathi Subramanian ${ }^{4}$, \\ Muhammad Khan ${ }^{1}$, Zain Ul Abideen Asad ${ }^{5}$, Swapna Talluri ${ }^{6}$, Aarthi Madhanakumar ${ }^{7}$, \\ Ahmad Lone ${ }^{8}$, Muhammad Khan ${ }^{9}$, Erin Michos ${ }^{10}$, and Mohamad Alkhouli ${ }^{11}$ \\ ${ }^{1}$ West Virginia University Hospitals \\ ${ }^{2}$ West Virginia University School of Medicine \\ ${ }^{3}$ Guthrie Robert Packer Hospital \\ ${ }^{4}$ Washington Hospital Healthcare System \\ ${ }^{5}$ University of Oklahoma Health Sciences Center \\ ${ }^{6}$ Guthrie Healthcare System \\ ${ }^{7}$ Allegheny Health Network \\ ${ }^{8}$ West Virginia University \\ ${ }^{9}$ John H Stroger Hospital of Cook County \\ ${ }^{10}$ Johns Hopkins University \\ ${ }^{11}$ Mayo Clinic
}

August 28, 2020

\begin{abstract}
Background: Representation trends of women, older adults, and ethnic/racial minorities in randomized controlled trials (RCTs) of atrial fibrillation (AF) are uncertain. Methods: We systematically reviewed 134 AF related RCTs (phase II and III) encompassing 149,162 participants using Medline and ClinicalTrials.gov through April 2019 to determine representation trends of women, older patients ([?] 75 years), and ethnic/racial minorities. Weighted data on the prevalence of AF from epidemiological studies were used to compare the representation of the studied groups of interest in AF RCTs to their expected burden of the disease. Results: Only $18.7 \%$ of the RCTs reported proportion of older patients, and $12.7 \%$ RCTs reported ethnic/racial minorities. In RCTs, proportions of women, Hispanics, Blacks, American Indian/Alaskan patients, Asians, native Hawaiian/Pacific Islanders and non-Whites were $35.2 \%, 11.9 \%, 1.2 \%, 0.2 \%, 14.2 \%, 0.05 \%$, and $19.5 \%$, respectively. The corresponding proportions in general population were $35.1 \%, 5.2 \%, 5.7 \%, 0.2 \%, 2.4 \%, 0.1 \%$, and $22.5 \%$, respectively. The weighted mean age (SD) across the trials was 65.3 (3.2) years which was less than the corresponding weighted mean age of 71.1 (4.5) years in the comparative epidemiological data. Conclusion: The reporting of older patients and ethnic/racial minorities was poor in RCTs of AF. The representation of women and American Indian/Alaskan natives matched their expected population share of disease burden. Hispanics and Asians were over-represented and Blacks, native Hawaiian/Pacific Islanders and non-Whites were under-represented in RCTs of AF. In nearly all studied RCTs, the reporting of racial demographics did not start until later part of last decade.
\end{abstract}




\section{INTRODUCTION}

Atrial fibrillation (AF) is the most common sustained arrhythmia in clinical practice ${ }^{1}$. Accumulating evidence suggest a strong link between sex, age and race with $\mathrm{AF}$ incidence 2, 3. Men have highest AF prevalance, with 20.9 out of 33.5 million AF patients (62.4\%) worldwide being men ${ }^{4}$. Despite the lower prevalence, women are at a greater risk for more devastating AF-related consequences such as stroke ${ }^{5-7}$. Also, it is well documented that the incidence, prevalence, and complications from AF increase with advancing age 8,9 . With regards to race-based differences, non-White population has been found to have a lower prevalence of AF compared with Whites ${ }^{10-12}$. Despite these statistics there are concerns that women, older patients and ethnic/racial minorities are under-represented in randomized controlled trials (RCTs) of cardiovascular disease such as AF compared with their share of disease in the population ${ }^{13}$. The under recruitment of women, older participants and ethnic/racial minorities in cardiovascular drug trials and heart failure trials has been examined in prior reports ${ }^{13-15}$; however, there is paucity of data regarding systematic assessment of these demographic subsets in RCTs of AF. Herein, we provide a systematic review on representation of women, older patients, ethnic/racial minorities and their time trends in published trials of AF from 1989-2019.

\section{METHODS}

This systematic review was performed in accordance with PRISMA (Preferred Reporting Items for Systematic Reviews and Meta-Analyses $)^{16}$. The systematic search was conducted by two independent investigators (S.T and A.N.L) using databases of MEDLINE and ClinicalTrials.gov from 1985 to April 2019. A broad search strategy was used to identify RCTs of AF in human subjects: (*Atrial fibrillation OR *AF) AND ( ${ }^{*}$ Rate control therapy OR *Rhythm control therapy OR *Ablation OR ${ }^{*}$ Cardioversion OR *Anticoagulation OR * Treatment) (Table supplementary S1). ClinicalTrials.gov was queried using following limits: Adult ([?]18 years), interventional, phase II-III and "atrial fibrillation". We also downloaded meta-analyses related to AF for additional information 17, 18. After removing duplicates, all the articles were scrutinized at the title and abstract level followed by review of full text to include phase II and III RCTs of adult human participants with follow-up of at least 3 months. While there was no restriction on sample size, we preferred 3-month follow-up to include maximum number of RCTs yet ensuring important data because relatively longer follow-up is considered to provide more accurate information ${ }^{13}$. The following data was extracted: (1) title, (2) year of publication, (3) journal, (4) total number of participants, (5) number of women, (6) mean or median age, (7) number of older patients, defined as [?]75 years, (8) ethnicity and race, (9) location, (10) funding sources, (11) types of RCTs (prevention of stroke or treatment of AF), and (12) baseline population. We reviewed ClinicalTrials.gov for any missing information not obtained from trial's manuscript. We followed the US Food and Drug Administration (FDA) position statement during data abstraction on ethnicity and race minorities ${ }^{19}$. Ethnicity was captured as Hispanic/Latino; Race was defined as: (1) African American or Black, (2) American Indian or Alaskan Native, (3) Native Hawaiian or other Pacific Islander, and (4) Asians. If study had characterized the race as non-White or race other than White was not clearly specified, we grouped data as non-White race. Location of RCTs were divided into (1) exclusively North America including United States, Canada, and Mexico; (2) exclusively Western Europe including Austria, Belgium, Bermuda, Denmark, Finland, France, Germany, Greece, Iceland, Ireland, Israel, Italy, Luxembourg, Netherlands, Norway, Portugal, Spain, Sweden, Switzerland, and United Kingdom; (3) rest of the world-exclusively outside of North America and Western Europe, and (4) Multi-regional. We classified funding sources as per ClinicalTrials.gov designations: government, academic center/university, industry or collaborative trials between non- profit organizations and industries ${ }^{13}$. Baseline population was categorized into non- valvular $\mathrm{AF}, \mathrm{AF}$ in mitral valve disease, $\mathrm{AF}$ in rheumatic valve disease, status post catheter ablation in $\mathrm{AF}$ and $\mathrm{AF}$ in miscellaneous groups (i.e. $\mathrm{AF}$ after cardioversion, $\mathrm{AF}$ in heart failure or with recent percutaneous coronary intervention). Further categorization of stroke prevention and AF treatment trials was done based on medications or interventions examined in RCTs. To examine proportion of these demographic subsets in 
our trial level data base relative to their representation in disease population, we selected comparative data from observational and epidemiological studies (Table S2) ${ }^{4,20-28}$. To most closely mirror the target population in AF RCTs, the relevant comparative data was selected to represent global disease burden including regions of North America, Western Europe, Asia and other regions. The data was weighted for sample size, i.e. weighted mean for women, age, ethnic/racial minorities was derived by multiplying the mean of each study by weighted number based on study's size relative to the total studies included. RCTs were grouped according to publication year starting from 1989-2019, with first and last group consisting of 5-year period and remaining groups of 4-year period. Continuous variables were reported as mean (standard deviations $[\mathrm{SD}]$ ) or median (interquartile range $[\mathrm{IQR}]$ ). Categorical variables were expressed as No. (\%). Categorical variables were compared using Pearson $\chi^{2}$ testing. One-way analysis of variance (ANOVA) test was used for testing significance of means and $\alpha$ was kept at 0.05. To test for a trend in demographic characteristics of the patient samples across the study period, we used simple linear regression models using year of publication as the independent variable. The dependent variables were the proportion of women, mean age of participants, proportion of $>75$ years old participants and the proportion of underrepresented minorities. Analyses were performed with IBM, version SPSS 24 (IBM Corporation) and Microsoft Excel (Microsoft Corporation).

\section{RESULTS}

A total of 134 RCTs (149,162 participants) were included (Figure S1; Table S3). The median number of participants per trial was 205 (IQR, 729-203). A total of 55 RCTs were based in Western Europe, 22 RCTS in North America, 35 RCTs were multiregional, and $32 \mathrm{RCTs}$ were conducted in rest of the world. Sixty RCTs were funded by academic center/university or organization, 41 RCTs were industry funded, 17 RCTs were government funded and 16 RCTs were conducted under collaboration between industry, academic center/organization. Trends in age, representation of women, race and ethnicity over time (1989-2019) are summarized in Table 1. Overall representation of women was $35.2 \%$ (Table S4), which matched the corresponding weighted proportion of women in epidemiological studies, i.e. 35.1\% (Figure-1). The representation of women varied from $26.2 \%$ to $44.5 \%$ from 1989-2019 ( $\mathrm{P}=0.30$; Figure 2A; Table S4). Women presentation was significantly higher in collaborative trials between industry and universities/academic centers (36.1\%), followed by industry funded trials $(34.8 \%)$ and government funded trials $(33.8 \%)(\mathrm{P}<0.01)$. Women enrollment did not significantly differ based on types of trials or baseline population. Linear regression did not show a significant association between women enrollment in trials with publication years (Figure S2). The weighted mean age across the trials was $65.3 \pm 3.2$ years which was less than the corresponding weighted mean age of $71.1 \pm 4.5$ years in the comparative epidemiological data (Figure-1). Mean age of participants was highest in North American RCTs (67.6 \pm 5.6 years) and lowest in RCTs conducted in rest of the world (58.8 \pm 10.9 years) $(\mathrm{P}<0.01$; Table $\mathrm{S} 4)$. Government funded RCTs (66.1 \pm 7.02 years) and industry funded RCTs $(66.7 \pm 5.7$ years $)$ had higher mean age as compared to academic center/university-based RCTs $(62.2 \pm 10.1$ years $)(\mathrm{P}<0.01)$. In stroke prevention RCTs, DOACs trials had lowest mean age (68.5 \pm 6.5 years), and watchman trials recruited participants with highest mean age of $73.3 \pm 1.5$ years $(\mathrm{P}<0.01)$. In $\mathrm{AF}$ treatment $\mathrm{RCTs}$, trials with different forms of pacing had patients with mean age of $69.1 \pm 5$ years, whereas, the mean age in trials assessing catheter ablation was $58.2 \pm 4.4$ years $(\mathrm{P}<0.01)$. Twenty-five $\mathrm{RCTs}$ reported distribution of patients according to age groups (Table S6). In these trials, the proportion of older patients ([?]75 yrs.) was $36.1 \%$ which was comparable to $34.8 \%$ weighted proportion in epidemiological data (Figure 1). The distribution of older participants did not significantly vary based on location of the trial, funding source, or baseline population of the trials. Linear regression showed no significant association between enrollment of older patients and publication years (Figure S3). RCTs conducted prior to 2007 lacked reporting on ethnic/racial minorities and only 17 RCTs reported enrollment of ethnic/racial minorities (Table S7). Among these RCTs, Hispanics represented 11.9\%, non-Whites 19.5\%, Blacks 1.2\%, Asians 14.2\%, American Indian/Alaskan natives 0.2\%, and native Hawaiian/Pacific Islanders $0.05 \%$. The weighted proportions in the comparative data were: Hispanics 5.2\%, non-Whites 22.5\%, 5.7\% Blacks, 2.4\% Asians, $0.1 \%$ native Hawaiian/Pacific Islanders and $0.2 \%$ American Indian/Alaskan natives (Figure-1). In North American RCTs, representation of Hispanics was 
$0.3 \%$, non-Whites $0.4 \%$, Blacks $0.2 \%$, Asians $0.1 \%$ and both native Hawaiian/Pacific Islanders and American Indians/Alaskan Natives was $<0.1 \%$. None of the western European RCTs reported enrollment with regards to ethnicity/races. There were no significant trends in enrollment rates of ethnic/racial minorities in terms of funding sources, baseline population or treatment strategies (Figure S3).

\section{DISCUSSION}

In this systematic review, reporting of older patients and ethnic/racial minorities was poor with $<20 \%$ of the included RCTs mentioning these demographic subsets. Enrollment of women and American Indian/Alaskan natives in RCTs of AF matched their demographic share of disease burden. Hispanics and Asians were over-represented and Blacks, native Hawaiian or Pacific Islander and non-Whites were under-represented in RCTs compared with real world data. Representation of women was significantly higher in industry or academic center sponsored RCTs compared with government funded RCTs. Mean age of participants was less than the corresponding weighted mean age in the comparative epidemiological data, and varied significantly based on location, funding sources, baseline population and according to management strategies used for prevention of stroke or treatment of AF. The 1993 National Institute of Health Revitalization act legally required RCTs to include men and women consistent with the known sex related prevalence of the disease under study. More recently, the Government Accountability Office (GAO) issued a follow-up report calling for improved reporting of women's enrollment in RCTs ${ }^{29}$. Since RCTs are regarded as the "gold standard" for shaping up the management strategies and guidelines, inclusion of women and demographic subgroups sustain the generalizability of the findings to the population as a whole and allows subgroup analyses to determine influence of different ethnicities. The current findings are in line with recent review by Scott and colleagues who also reported adequate representation of women in the RCTs that supported FDA approval of cardiovascular drugs ${ }^{15}$. However, women with $\mathrm{AF}$ were reported to have lower quality of life, higher risk of ischemic stroke and higher mortality as compared to men ${ }^{5-7}$. Therefore, such complexity of AF in women endorses the need for adequate enrollment in future RCTs as well. Our finding of lower proportion of women in government funded RCTs needs attention in this regard. The FDA guidelines in 1977 called for exclusion of women of childbearing potential from early phases of RCTs. Even though, such policies have been revised since that time, it is still plausible that this may have deterred female recruitment in RCTs especially the ones sponsored by the Government agencies ${ }^{30}$. Additionally, lack of awareness about RCTs and logistical barriers might also have contributed to the lower enrollment rates. Co-morbidities leading to AF vary based on age, sex and ethnicities ${ }^{31,32}$. The prevalence of AF rises steadily with age, and Blacks have a 2-5 times higher risk of AF-associated stroke than Whites. However, the enrollment of older patients was reported in only $18.7 \%$ of the included RCTs. Similarly, only $12.7 \%$ RCTs reported ethnic/racial population, out of which Black patients made up disappointingly $<2 \%$ of cohorts. In order to improve enrollment of these groups, following strategies can be considered. First, greater cultural sensitivity is needed to ensure adequate recruitment and consent procedures that are consistent with different ethnic/racial cultures ${ }^{33}$. Second, targeting inner city population that are likely to have a high minority ethnic population and hiring special advocacy workers to provide a bridge between recruiters and minority population ${ }^{34}$. Third, addressing the obstacles for women participation such as offering childcare or transportation, having special considerations when enrolling fertile women, and ensuring they have access to counseling and medical care ${ }^{35}$. Fourth, an Office of Geriatric Health and Aging can be created to review protocols and enrollment of older population similar to the workings of Office of Women's Health which was established by Congressional mandate in $1994{ }^{32}$. Fifth, simplifying consent forms, adding time to consult with family, the use of proxy data or remote follow up can be elicited to overcome barriers to participation of underrepresented demographics in RCTs ${ }^{32}$. Our study has certain limitations. Since we did not have access to individual participant's data, this review was limited to trial-level information. We relied on published trials and thus risk of publication bias cannot be ignored. Overall, there was inadequate reporting of older patients and ethnic/racial minorities in AF RCTs. The representation of racial demographics did not start until 2007 in AF RCTs with reporting on certain races such as Native Hawaiian or Pacific Islanders beginning in 2011. This limit inferring strong conclusion 
around such racial demographics. Furthermore, some RCTs have only reported race as White or non-White which makes detailed analysis of non-White racial groups impossible from those studies. Additionally, one can argue that treatments in RCTs are examined to determine effects in population at risk, and naturally stroke prevention trials would reflect older cohorts given higher inherent risk of stroke compared with younger participants in catheter ablation trials. In conclusion, this systematic review suggests adequate enrollment of women, older patients and American Indian/Alaskan natives, over recruitment of Hispanics and Asians and under recruitment of Blacks, non-Whites and native Hawaiian or Pacific Islanders in Trials of AF compared with their demographic share of disease burden. These data demand a diligent review of the policies by organizations and investigators to ensure adequate representation of these demographic subgroups in future RCTs.

\section{Figure legends}

Figure 1: Central Illustration: Proportion of Inclusion of Women, Older Adults, and Ethnic/Racial Minorities in Clinical Trials of Atrial Fibrillation Compared with Their Disease Prevalence Reported in Epidemiological Studies Figure 2A: Trends of Representation of Women in Clinical Trials of Atrial Fibrillation Figure 2B: Trends of Representation of Mean Age in Clinical Trials of Atrial Fibrillation

\section{REFERENCES}

Wyndham CR. Atrial fibrillation: the most common arrhythmia. Tex Heart Inst J .

2000;27:257-267.

1. Bukari A, Nayak H, Aziz Z, Deshmukh A, Tung R and Ozcan C. Impact of race and gender on clinical outcomes of catheter ablation in patients with atrial fibrillation. Pacing Clin Electrophysiol . 2017;40:1073-1079.

2. Wolbrette D. Antiarrhythmic Drugs: Age, Race, and Gender Effects.Card Electrophysiol Clin . 2010;2:369-378.

3. Chugh SS, Havmoeller R, Narayanan K, Singh D, Rienstra M, Benjamin EJ, Gillum RF, Kim YH, McAnulty JH, Jr., Zheng ZJ, Forouzanfar MH, Naghavi M, Mensah GA, Ezzati M and Murray CJ. Worldwide epidemiology of atrial fibrillation: a Global Burden of Disease 2010 Study.Circulation . 2014;129:837-847.

4. Friberg J, Scharling H, Gadsboll N, Truelsen T, Jensen GB and Copenhagen City Heart S. Comparison of the impact of atrial fibrillation on the risk of stroke and cardiovascular death in women versus men (The Copenhagen City Heart Study). The American journal of cardiology . 2004;94:889-894.

5. Lip GY, Laroche C, Boriani G, Cimaglia P, Dan GA, Santini M, Kalarus Z, Rasmussen LH, Popescu MI, Tica O, Hellum CF, Mortensen B, Tavazzi L and Maggioni AP. Sex-related differences in presentation, treatment, and outcome of patients with atrial fibrillation in Europe: a report from the Euro Observational Research Programme Pilot survey on Atrial Fibrillation. Europace . 2015;17:24-31.

6. Asad Z, Abbas M, Javed I, Korantzopoulos P and Stavrakis S. Obesity is associated with incident atrial fibrillation independent of gender: A meta-analysis. J Cardiovasc Electrophysiol . 2018;29:725-732.

7. Piccini JP, Hammill BG, Sinner MF, Jensen PN, Hernandez AF, Heckbert SR, Benjamin EJ and Curtis LH. Incidence and prevalence of atrial fibrillation and associated mortality among Medicare beneficiaries, 1993-2007. Circ Cardiovasc Qual Outcomes . 2012;5:85-93.

8. Piccini JP, Hammill BG, Sinner MF, Hernandez AF, Walkey AJ, Benjamin EJ, Curtis LH and Heckbert SR. Clinical course of atrial fibrillation in older adults: the importance of cardiovascular events beyond stroke. European heart journal . 2014;35:250-256.

9. Dewland TA, Olgin JE, Vittinghoff E and Marcus GM. Incident atrial fibrillation among Asians, Hispanics, blacks, and whites. Circulation . 2013;128:2470-2477. 
10. Shen AY, Contreras R, Sobnosky S, Shah AI, Ichiuji AM, Jorgensen MB, Brar SS and Chen W. Racial/ethnic differences in the prevalence of atrial fibrillation among older adults-a cross-sectional study.J Natl Med Assoc . 2010;102:906-913.

11. Magnani JW, Norby FL, Agarwal SK, Soliman EZ, Chen LY, Loehr LR and Alonso A. Racial Differences in Atrial Fibrillation-Related Cardiovascular Disease and Mortality: The Atherosclerosis Risk in Communities (ARIC) Study. JAMA cardiology . 2016;1:433-441.

12. Tahhan AS, Vaduganathan M, Greene SJ, Fonarow GC, Fiuzat M, Jessup M, Lindenfeld J, O'Connor $\mathrm{CM}$ and Butler J. Enrollment of Older Patients, Women, and Racial and Ethnic Minorities in Contemporary Heart Failure Clinical Trials: A Systematic Review. JAMA cardiology. 2018;3:1011-1019.

13. Melloni C, Berger JS, Wang TY, Gunes F, Stebbins A, Pieper KS, Dolor RJ, Douglas PS, Mark DB and Newby LK. Representation of women in randomized clinical trials of cardiovascular disease prevention. Circ Cardiovasc Qual Outcomes . 2010;3:135-142.

14. Scott PE, Unger EF, Jenkins MR, Southworth MR, McDowell TY, Geller RJ, Elahi M, Temple RJ and Woodcock J. Participation of Women in Clinical Trials Supporting FDA Approval of Cardiovascular Drugs. Journal of the American College of Cardiology . 2018;71:1960-1969.

15. Liberati A, Altman DG, Tetzlaff J, Mulrow C, Gotzsche PC, Ioannidis JP, Clarke M, Devereaux PJ, Kleijnen $\mathrm{J}$ and Moher D. The PRISMA statement for reporting systematic reviews and meta-analyses of studies that evaluate healthcare interventions: explanation and elaboration. BMJ . 2009;339:b2700.

16. Khan SU, Khan MU, Ghani AR, Lone AN, Arshad A and Kaluski E. Meta-Analysis of Antithrombotic Therapy in Atrial Fibrillation After Percutaneous Coronary Intervention. The American journal of cardiology . 2018;121:1200-1206.

17. Khan SU, Rahman H, Talluri S and Kaluski E. The Clinical Benefits and Mortality Reduction Associated With Catheter Ablation in Subjects With Atrial Fibrillation: A Systematic Review and Meta-Analysis. JACC Clinical electrophysiology . 2018;4:626- 635.

18. FDA. Collection of Race and Ethnicity Data in Clinical Trials. 2016.

19. Heeringa J, van der Kuip DA, Hofman A, Kors JA, van Herpen G, Stricker BH, Stijnen T, Lip GY and Witteman JC. Prevalence, incidence and lifetime risk of atrial fibrillation: the Rotterdam study. European heart journal . 2006;27:949-953.

20. Go AS, Hylek EM, Phillips KA, Chang Y, Henault LE, Selby JV and Singer DE. Prevalence of diagnosed atrial fibrillation in adults: national implications for rhythm management and stroke prevention: the AnTicoagulation and Risk Factors in Atrial Fibrillation (ATRIA) Study.Jama . 2001;285:2370-2375.

21. Kodani E and Atarashi H. Prevalence of atrial fibrillation in Asia and the world.

Journal of Arrhythmia. 2012;28:330-337.

1. Nisar MU, Munir MB, Sharbaugh MS, Thoma FW, Althouse AD and Saba S. Trends in atrial fibrillation hospitalizations in the United States: A report using data from the National Hospital Discharge Survey.Indian Pacing Electrophysiol J . 2018;18:6-12.

2. Zarifis J, Beevers G and Lip GY. Acute admissions with atrial fibrillation in a British multiracial hospital population. The British journal of clinical practice . 1997;51:91- 96.

3. Davis RC, Hobbs FD, Kenkre JE, Roalfe AK, Iles R, Lip GY and Davies MK. Prevalence of atrial fibrillation in the general population and in high-risk groups: the ECHOES study. Europace . 2012;14:15531559 .

4. Lloyd-Jones DM, Wang TJ, Leip EP, Larson MG, Levy D, Vasan RS, D'Agostino RB, Massaro JM, Beiser A, Wolf PA and Benjamin EJ. Lifetime risk for development of atrial fibrillation: the Framingham Heart Study. Circulation. 2004;110:1042-1046.

5. Guo Y, Tian Y, Wang H, Si Q, Wang Y and Lip GYH. Prevalence, incidence, and lifetime risk of atrial fibrillation in China: new insights into the global burden of atrial fibrillation. Chest . 2015;147:109-119.

6. Shulman E, Kargoli F, Mittell A, Hoch E, DiBiase L, Fisher J, Gross J, Kim S, Ferrick KJ and Krumerman A. 073_16751-H1 Atrial Fibrillation in Hispanics, Blacks and Whites with Heart Failure. JACC: Clinical Electrophysiology . 2017;3:S5.

7. Health E. Do Clinical Trials Have a Sex Problem? 2018. 
8. Merkatz RB. Inclusion of women in clinical trials: a historical overview of scientific, ethical, and legal issues. J Obstet Gynecol Neonatal Nurs . 1998;27:78-84.

9. Krecic-Shepard ME, Park K, Barnas C, Slimko J, Kerwin DR and Schwartz JB. Race and sex influence clearance of nifedipine: results of a population study. Clin Pharmacol Ther . 2000;68:130-142.

10. Skolnick AH and Alexander KP. Older Adults in Clinical Research and Drug Development: Closing the Geriatric Gap. Circ Cardiovasc Qual Outcomes . 2015;8:631- 633.

11. Informed Consent of Subjects Who Do Not Speak English (1995).

12. Hussain-Gambles M, Atkin K and Leese B. Why ethnic minority groups are under-represented in clinical trials: a review of the literature. Health Soc Care Community . 2004;12:382-388.

13. McCullough LB, Coverdale JH and Chervenak FA. Preventive ethics for including women of childbearing potential in clinical trials. Am J Obstet Gynecol . 2006;194:1221- 1227.

Table 1Table 1. Trends in Age, Sex, and Race/Ethnicity of Contemporary Clinical Trials of Atrial Fibrillation (1989-2019)

\begin{tabular}{|c|c|c|c|c|c|c|c|c|}
\hline $\begin{array}{l}\text { Median } \\
\text { (IQR) }\end{array}$ & $\begin{array}{l}\text { Median } \\
\text { (IQR) }\end{array}$ & $\begin{array}{l}\text { Median } \\
\text { (IQR) }\end{array}$ & $\begin{array}{l}\text { Median } \\
\text { (IQR) }\end{array}$ & $\begin{array}{l}\text { Median } \\
\text { (IQR) }\end{array}$ & $\begin{array}{l}\text { Median } \\
\text { (IQR) }\end{array}$ & $\begin{array}{l}\text { Median } \\
\text { (IQR) }\end{array}$ & $\begin{array}{l}\text { Median } \\
\text { (IQR) }\end{array}$ & $\begin{array}{l}\text { Media } \\
\text { (IQR) }\end{array}$ \\
\hline Characteris & $\begin{array}{l}\text { tik989- } \\
1994\end{array}$ & $\begin{array}{l}1995- \\
1998\end{array}$ & $\begin{array}{l}1999- \\
2002\end{array}$ & $\begin{array}{l}2003- \\
2006\end{array}$ & $\begin{array}{l}2007- \\
2010\end{array}$ & $\begin{array}{l}2011- \\
2014\end{array}$ & $\begin{array}{l}2015- \\
2019\end{array}$ & P-valu \\
\hline Trials, No. & 7 & 4 & 11 & 25 & 20 & 32 & 35 & NA \\
\hline $\begin{array}{l}\text { Total } \\
\text { partici- } \\
\text { pants, } \\
\text { No. }\end{array}$ & 5767 & 2680 & 6602 & 11713 & 24272 & 68504 & 29624 & NA \\
\hline $\begin{array}{l}\text { Participants } \\
\text { per } \\
\text { trial, } \\
\text { median } \\
(\mathrm{IQR})\end{array}$ & $\begin{array}{l}846.3 \\
(378- \\
1330)\end{array}$ & $\begin{array}{l}796.5 \\
(43- \\
1044)\end{array}$ & $\begin{array}{l}136(20- \\
4060)\end{array}$ & $\begin{array}{l}137(29- \\
6706)\end{array}$ & $\begin{array}{l}163.5(49- \\
18113)\end{array}$ & $\begin{array}{l}229(41- \\
21026)\end{array}$ & $\begin{array}{l}238(21- \\
6351)\end{array}$ & 0.54 \\
\hline $\begin{array}{l}\text { Weighted } \\
\text { age, } \\
\text { mean } \\
(\mathrm{SD})\end{array}$ & $\begin{array}{l}69.5 \\
(3.2)\end{array}$ & $\begin{array}{l}70.5 \\
(3.8)\end{array}$ & $\begin{array}{l}67.4 \\
(5.0)\end{array}$ & $\begin{array}{l}62.3 \\
(10.1)\end{array}$ & $\begin{array}{l}62.8 \\
(10.1)\end{array}$ & $\begin{array}{l}64.2 \\
(9.9)\end{array}$ & $\begin{array}{l}64.4 \\
(5.7)\end{array}$ & 0.24 \\
\hline $\begin{array}{l}\text { Weighted } \\
\text { women, } \\
\text { No. }(\%)\end{array}$ & 26.2 & 44.5 & 42.7 & 35.6 & 35.4 & 36.7 & 30.4 & 0.54 \\
\hline $\begin{array}{l}\text { Trials } \\
\text { reporting } \\
\text { partici- } \\
\text { pants [?] } 75 \\
\text { yrs., No. }\end{array}$ & 3 & NR & NR & 2 & 2 & 12 & 8 & 0.374 \\
\hline $\begin{array}{l}\text { Total } \\
\text { partici- } \\
\text { pants } \\
{[?] 75} \\
\text { yrs., No. }\end{array}$ & 5767 & NR & NR & 11713 & 24272 & 68504 & 29624 & NA \\
\hline $\begin{array}{l}\text { Participants } \\
{[?] 75} \\
\text { yrs., No. } \\
(\%)\end{array}$ & $\begin{array}{l}849 \\
(14.7)\end{array}$ & NR & NR & $\begin{array}{l}10764 \\
(91.4)\end{array}$ & $\begin{array}{l}159 \\
(0.7)\end{array}$ & $23888(34.9)$ & $4007(13.5)$ & 0.136 \\
\hline
\end{tabular}




\begin{tabular}{|c|c|c|c|c|c|c|c|c|}
\hline $\begin{array}{l}\text { Median } \\
\text { (IQR) }\end{array}$ & $\begin{array}{l}\text { Median } \\
\text { (IQR) }\end{array}$ & $\begin{array}{l}\text { Median } \\
\text { (IQR) }\end{array}$ & $\begin{array}{l}\text { Median } \\
\text { (IQR) }\end{array}$ & $\begin{array}{l}\text { Median } \\
\text { (IQR) }\end{array}$ & $\begin{array}{l}\text { Median } \\
\text { (IQR) }\end{array}$ & $\begin{array}{l}\text { Median } \\
\text { (IQR) }\end{array}$ & $\begin{array}{l}\text { Median } \\
\text { (IQR) }\end{array}$ & $\begin{array}{l}\text { Media } \\
\text { (IQR) }\end{array}$ \\
\hline $\begin{array}{l}\text { Trials } \\
\text { reporting } \\
\text { non-White, } \\
\text { No. }\end{array}$ & NR & NR & NR & NR & 3 & 6 & 7 & $\mathrm{NA}$ \\
\hline $\begin{array}{l}\text { Non- } \\
\text { Whites, } \\
\text { No. (\%) }\end{array}$ & NR & NR & NR & NR & $\begin{array}{l}5464 \\
(36.0)\end{array}$ & $\begin{array}{l}8483 \\
(56.0)\end{array}$ & $\begin{array}{l}1214 \\
(8.0)\end{array}$ & 0.27 \\
\hline $\begin{array}{l}\text { Trials } \\
\text { reporting } \\
\text { Blacks, No. }\end{array}$ & NR & NR & NR & NR & 2 & 5 & 7 & $\mathrm{NA}$ \\
\hline $\begin{array}{l}\text { Blacks, } \\
\text { No. (\%) }\end{array}$ & NR & NR & NR & NR & $\begin{array}{l}178 \\
(18.3)\end{array}$ & $\begin{array}{l}559 \\
(57.5)\end{array}$ & $\begin{array}{l}235 \\
(24.2)\end{array}$ & 0.34 \\
\hline $\begin{array}{l}\text { Trials } \\
\text { reporting } \\
\text { Asians, No. }\end{array}$ & NR & NR & NR & NR & 2 & 7 & 6 & $\mathrm{NA}$ \\
\hline $\begin{array}{l}\text { Asians, } \\
\text { No. (\%) }\end{array}$ & NR & NR & NR & NR & $\begin{array}{l}2786 \\
(25.8)\end{array}$ & $\begin{array}{l}7387 \\
(68.3)\end{array}$ & $\begin{array}{l}642 \\
(5.9)\end{array}$ & 0.21 \\
\hline $\begin{array}{l}\text { Trials } \\
\text { reporting } \\
\text { native } \\
\text { Hawaiian } \\
\text { or Pacific } \\
\text { Islanders, } \\
\text { No. }\end{array}$ & NR & NR & NR & NR & NR & 3 & 1 & $\mathrm{NA}$ \\
\hline $\begin{array}{l}\text { Native } \\
\text { Hawai- } \\
\text { ian or } \\
\text { Pacific } \\
\text { Is- } \\
\text { landers, } \\
\text { No. }(\%)\end{array}$ & NR & NR & NR & NR & NR & $\begin{array}{l}10 \\
(90.1)\end{array}$ & $1(9.1)$ & 0.22 \\
\hline $\begin{array}{l}\text { Trials } \\
\text { reporting } \\
\text { American } \\
\text { Indian or } \\
\text { Alaskan } \\
\text { Natives, } \\
\text { No. }\end{array}$ & NR & NR & NR & NR & 1 & 3 & 2 & $\mathrm{NA}$ \\
\hline $\begin{array}{l}\text { American } \\
\text { Indian } \\
\text { or } \\
\text { Alaskan } \\
\text { Native, } \\
\text { No. }(\%)\end{array}$ & NR & NR & NR & NR & $1(1.2)$ & $\begin{array}{l}63 \\
(76.8)\end{array}$ & $\begin{array}{l}18 \\
(22.0)\end{array}$ & 0.71 \\
\hline $\begin{array}{l}\text { Trials } \\
\text { reporting } \\
\text { Hispanics, } \\
\text { No. }\end{array}$ & NR & NR & NR & NR & 2 & 3 & 6 & $\mathrm{NA}$ \\
\hline
\end{tabular}




\section{Location}

North American, No. (\%)

\begin{tabular}{lllllll}
\hline $5(22.7)$ & $1(4.5)$ & $2(9.1)$ & $2(9.1)$ & $2(9.1)$ & $2(9.1)$ & $8(36.4)$ \\
\hline $1(1.8)$ & $3(5.5)$ & $9(16.4)$ & $16(29.1)$ & $9(16.4)$ & $7(12.7)$ & $10(18.2)$ \\
& & & & & & \\
$\mathrm{NR}$ & $\mathrm{NR}$ & $\mathrm{NR}$ & $1(4)$ & $4(16)$ & $10(40)$ & $10(40)$ \\
$1(3.1)$ & $\mathrm{NR}$ & $\mathrm{NR}$ & $6(18.8)$ & $5(15.6)$ & $13(40.6)$ & $7(21.9)$ \\
& & & & & & \\
$3(17.6)$ & $\mathrm{NR}$ & $2(11.8)$ & $3(17.6)$ & $1(5.9)$ & $4(23.5)$ & $4(23.5)$ \\
$3(5)$ & $3(5)$ & $6(10)$ & $15(25)$ & $12(20)$ & $9(15)$ & $12(20)$ \\
$\mathrm{NR}$ & $1(2.4)$ & $2(4.9)$ & $6(14.6)$ & $6(14.6)$ & $14(34.1)$ & $12(29.3)$ \\
\hline
\end{tabular}

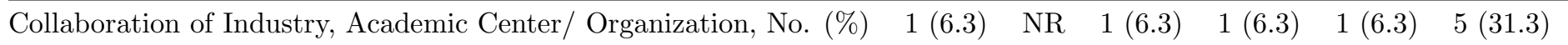

\section{Types of trials}

\begin{tabular}{|c|c|c|c|c|c|c|c|c|}
\hline $\begin{array}{l}\text { Stroke } \\
\text { prevention, } \\
\text { No. }(\%)\end{array}$ & $7(13.5)$ & $3(5.8)$ & $2(3.8)$ & $6(11.5)$ & $4(7.7)$ & $17(32.7)$ & $13(25)$ & \\
\hline $\begin{array}{l}\text { Treatment } \\
\text { of } \\
\text { AF/antiarrl } \\
\text { therapy, } \\
\text { No. } \\
(\%)\end{array}$ & $\begin{array}{l}\text { NR } \\
\text { thmic }\end{array}$ & NR & $5(20.8)$ & $6(25.0)$ & $4(16.7)$ & $2(8.3)$ & $7(29.2)$ & \\
\hline $\begin{array}{l}\text { Treatment } \\
\text { of AF/rate } \\
\text { control } \\
\text { therapy, } \\
\text { No. }(\%)\end{array}$ & NR & NR & $1(16.7)$ & $2(33.3)$ & $2(33.3)$ & $1(16.7)$ & NR & 0.03 \\
\hline $\begin{array}{l}\text { Treatment } \\
\text { of AF/ } \\
\text { surgical } \\
\text { ablation, } \\
\text { No. }(\%)\end{array}$ & NR & NR & $2(9.1)$ & $6(27.3)$ & $6(27.3)$ & $4(18.2)$ & $4(18.2)$ & \\
\hline
\end{tabular}

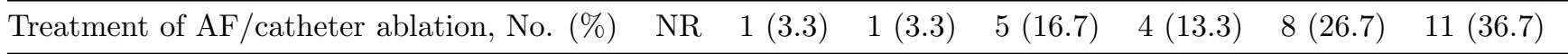

\section{Baseline population in trials}


Non

valvular

AF, No.

\begin{tabular}{llllllll}
$(\%)$ & $6(7.8)$ & $4(5.2)$ & $8(10.4)$ & $17(22.1)$ & $11(14.3)$ & $19(24.7)$ & $12(15.6)$ \\
\hline AF in & NR & NR & $2(16.7)$ & $5(41.7)$ & $2(16.7)$ & $1(8.3)$ & $2(16.7)$
\end{tabular}

Rheumatic

valve

disease, No.

(\%)

$\mathrm{AF}$ in

$1(3.6)$

NR

NR

$2(7.1)$

$4(14.3)$

7 (25)

$14(50)$

0.01

disease, No.

(\%)

Status

NR

NR

$1(8.3)$

NR

NR

$4(33.3)$

7 (58.3)

post

catheter

ablation

in $\mathrm{AF}$,

No. (\%)

\begin{tabular}{lllllllll}
\hline AF in miscellaneous group, No. (\%) & NR & NR & NR & $1(20)$ & $3(60)$ & $1(20)$ & NR \\
\hline
\end{tabular}

Trials of stroke prevention

\begin{tabular}{lllllllll}
\hline Warfarin $v$ antiplatelets or DOACs, No. $(\%)$ & $6(13)$ & $3(6.5)$ & $2(4.3)$ & $6(13)$ & $4(8.7)$ & $13(28.3)$ & $12(26.1)$ & \\
\hline DOACs $v$ control, No. $(\%)$ & $1(25)$ & NR & NR & NR & NR & $2(50)$ & $1(25)$ & 0.08 \\
\hline
\end{tabular}

\begin{tabular}{llllllll}
\hline Watchman $v$ warfarin, No. (\%) & NR & NR & NR & NR & NR & $2(100)$ & NR \\
\hline
\end{tabular}

\section{Trials of AF treatment}

\begin{tabular}{|c|c|c|c|c|c|c|}
\hline Catheter ablation $v$ rate control therapy, No. (\%) & NR & NR & NR & $3(15.8)$ & $3(15.8)$ & $4(21.1)$ \\
\hline $\begin{array}{l}\text { Catheter ablation } v \text { antiarrhythmic therapy, No. } \\
(\%)\end{array}$ & NR & $1(5.3)$ & $1(5.3)$ & $5(26.3)$ & $3(15.8)$ & $5(26.3)$ \\
\hline $\begin{array}{l}\text { Rate control therapy } v \text { rhythm control therapy, } \\
\text { No. }(\%)\end{array}$ & NR & NR & $4(23.5)$ & $6(35.3)$ & $5(29.4)$ & $1(5.9)$ \\
\hline $\begin{array}{l}\text { Surgical ablation } v \text { control/catheter ablation, } \\
\text { No. }(\%)\end{array}$ & NR & NR & $2(14.3)$ & $3(21.4)$ & $4(28.6)$ & $3(21.4)$ \\
\hline Antiarrhythmic therapy $v$ control/no antiarrhythmics, No. (\%) & NR & NR & $1(16.7)$ & NR & NR & $1(16.7)$ \\
\hline Different approaches for pacing & NR & NR & $1(20)$ & $2(40)$ & $1(20)$ & $1(20)$ \\
\hline
\end{tabular}

\begin{tabular}{llllllll}
\hline Ranolazine $v$ placebo & NR & NR & NR & NR & NR & NR & $2(100)$ \\
\hline
\end{tabular}


IQR; Interquartile Range, SD; Standard Deviation, NR; Not represented, NA; Not applicable, AF; Atrial fibrillation, DOAC; Direct oral anticoagulantsFigure 1

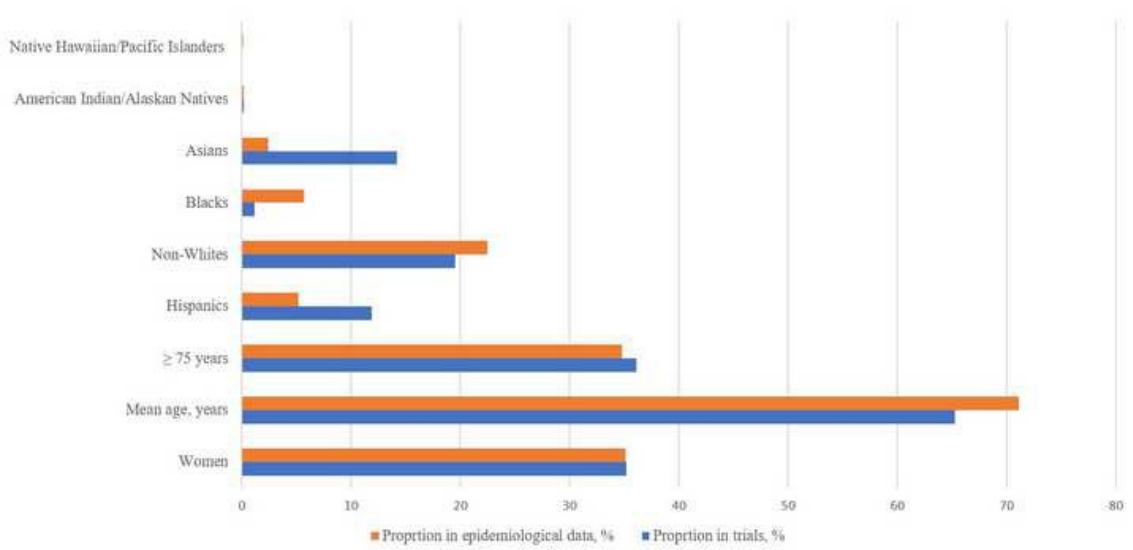

Figure 2A

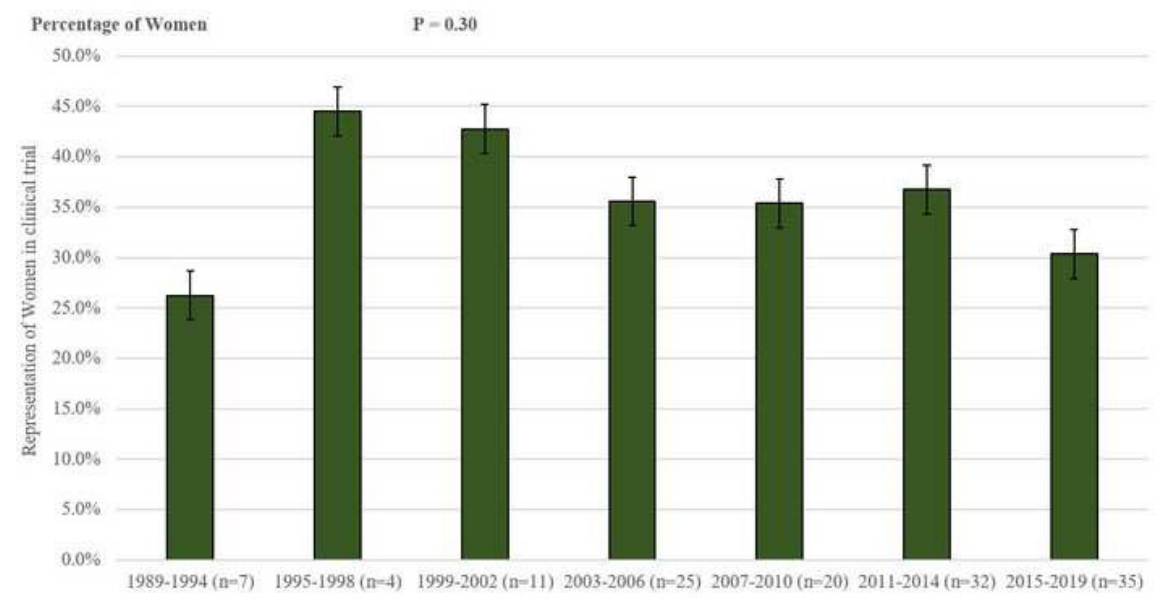

Figure 2B

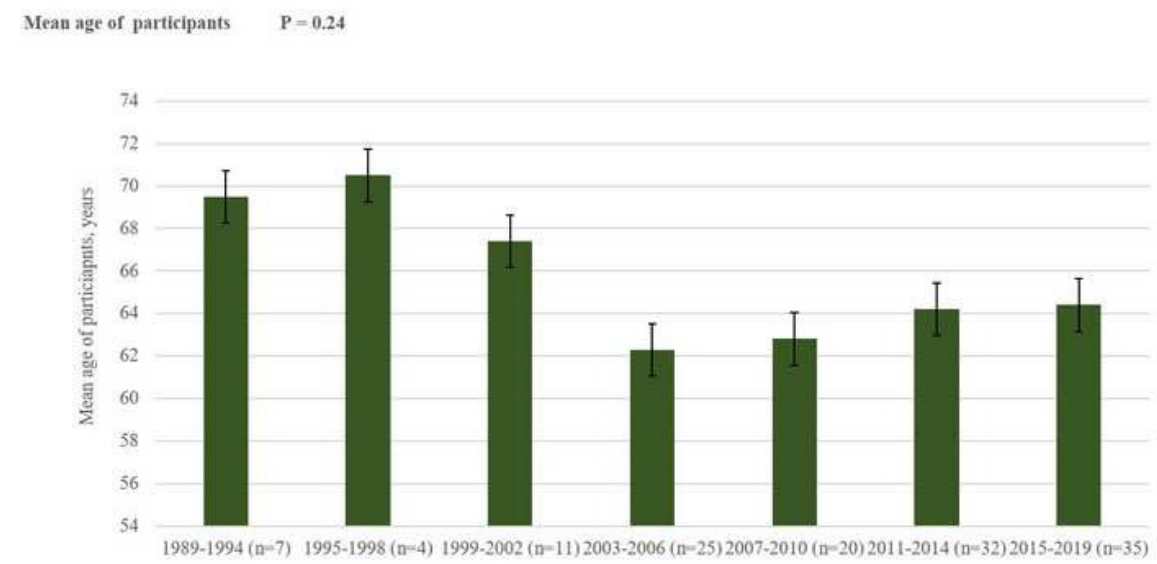

